\title{
Human-Biometeorological Assessment of Urban Structures in Extreme Climate Conditions: The Example of Birobidzhan, Russian Far East
}

\author{
Jan Paul Bauche, ${ }^{1}$ Elena A. Grigorieva, ${ }^{2}$ and Andreas Matzarakis ${ }^{1}$ \\ ${ }^{1}$ Chair of Meteorology and Climatology, Albert Ludwigs University Freiburg, Werthmannstraße 10, 79085 Freiburg, Germany \\ ${ }^{2}$ Institute for Complex Analysis of Regional Problems, Far Eastern Branch, Russian Academy of Sciences, Birobidzhan 679016, Russia \\ Correspondence should be addressed to Jan Paul Bauche; paul@mbauche.de
}

Received 4 June 2013; Revised 27 August 2013; Accepted 23 September 2013

Academic Editor: Marialena Nikolopoulou

Copyright (C) 2013 Jan Paul Bauche et al. This is an open access article distributed under the Creative Commons Attribution License, which permits unrestricted use, distribution, and reproduction in any medium, provided the original work is properly cited.

\begin{abstract}
The study shows the effect of urban structures on human thermal comfort indices in the extreme climate region of the Russian Far East, with an annual temperature range of $75^{\circ} \mathrm{C}$. The study examines different urban zones in Birobidzhan, the capital city of the Jewish Autonomous Region (JAR). The climate of this region can be characterized as continental monsoon climate. The difference of thermal values for three zones with different vegetation and build-up density shows the influence of urban planning on the local microclimate. The moderating effect of dense build-up and inner city vegetation on extreme thermal conditions becomes clear when comparing all zones. Through the analysis of daily and monthly timelines it was possible to determine preferable times of the day for inner city outdoor activities. From the results derived from PET with a total of 170 days per year with PET values below $0^{\circ} \mathrm{C}$ Birobidzhan can be considered a region of extreme cold stress. This means that an adaptation based solely on behaviour and clothing is not sufficient, but an adaptation of the urban surroundings and therefore the identification and choice of preferable urban structures is necessary.
\end{abstract}

\section{Introduction}

Since the last decades of the 20th century and due to the challenges of climate change, climatological and meteorological parameters have been in the focus of urban planning. Most of those studies assess the standard meteorological parameters associated with human thermal comfort such as air temperature, global radiation, wind velocity, relative humidity, or precipitation. However, if they are assessed just by themselves, the results are taken out of the human context and lose their original purpose. To put them into context, the application of complex and differentiated human bioclimate indices is needed. For the purpose of this study two of these indices haven been applied to the meteorological conditions and the urban structures of Birobidzhan, the capital city of the Jewish Autonomous Region (JAR), at the Russian Far East. In the course of a year this region experiences all facets of extreme meteorological conditions from arid cold to humid warm (Figure 1). This makes the region of the JAR extremely suitable for the purpose of analysing the impact of urban structures on the human thermal comfort assuming an intensification of extreme meteorological conditions in presently moderate climate areas, due to the global climate change. During the last 20 years the interest in the human thermal bioclimate has been rising due to great awareness of the influence of climate on our lives which is strongly connected to the public debate about climate change and its influence on everyday life. As a result of this development regions that are already under the influence of harsh climates are very interesting for analysis of climate change results.

The indices used for this study are the physiologically equivalent temperature (PET) based on the Munich Energybalance Model for Individuals (MEMI) [1-3], displayed in degrees Celsius $\left({ }^{\circ} \mathrm{C}\right)$ which makes it easy to comprehend and easy to be compared to other indices or measurement, and the universal thermal climate index (UTCI), also displayed in ${ }^{\circ} \mathrm{C}$, which is based on a multinode human energy balance model for a more adaptive approach to extreme climate conditions 


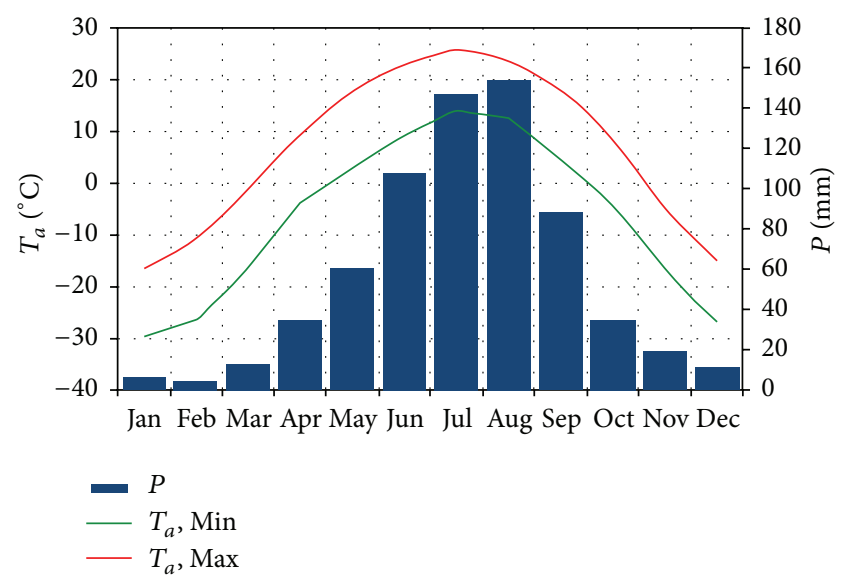

FIgURE 1: Climate diagram for the Birobidzhan area (data source: http://worldweather.wmo.int/).

$[4,5]$. A selection of studies conducted in the JAR, and such concerning the topic of the human biometeorology, is displayed to show what has been done so far. Studies on this topic have been published since the late eighties $[1,6]$. They show the development and application of PET based on the human energy balance model MEMI $[1-3,7,8]$ and the RayMan model $[9,10]$ and the effect of shading on outdoor comfort $[11,12]$ as well as the development of UTCI $[5,13,14]$ and the underlying multinode model $[4,15-17]$. In the following years, papers concerning the bioclimate of the JAR, focusing on the efficiency of agricultural crop growing and outdoor recreation and tourism, were published [1822]. These works are designed to find preferable outdoor activities or to quantify the influence of the regional climate on crop seasons and are usually based on daily and monthly climate data. This study aims to give an actual and accurate assessment of the human thermal bioclimate and to find preferable city structures or at least preferable inner city locations at any given time of day in the city of Birobidzhan using a high temporal resolution of meteorological data.

\section{Area of Investigation}

Birobidzhan is located close to the Chinese northern border at $48^{\circ} \mathrm{N}$ and $132^{\circ} \mathrm{E}$ (Figure 2) with a mean altitude of $76 \mathrm{~m}$ a.sl. and is inhabited about 75,000 people on an area of $169 \mathrm{~km}^{2}$. Even though the latitude coincides with a moderate climate by the climate in the Jewish Autonomous Region (JAR), of which Birobidzhan is the capital, is far from moderate. Its continental exposition leads to cold winters and warm summers. This effect is intensified by the influence of the summer monsoon and its close proximity to the Siberian high pressure field resulting in an annual variation in air temperature of up to $75^{\circ} \mathrm{C}$ in the course of six months in extreme cases. Due to this variation the annual course of the meteorological factors in this region shows great variability. From a mean maximum air temperature of about $26^{\circ} \mathrm{C}$ in July to $-29^{\circ} \mathrm{C}$ in January and a monthly precipitation of $154 \mathrm{~mm}$ in August to $5 \mathrm{~mm}$ in February all facets of an extreme climate can be experienced.

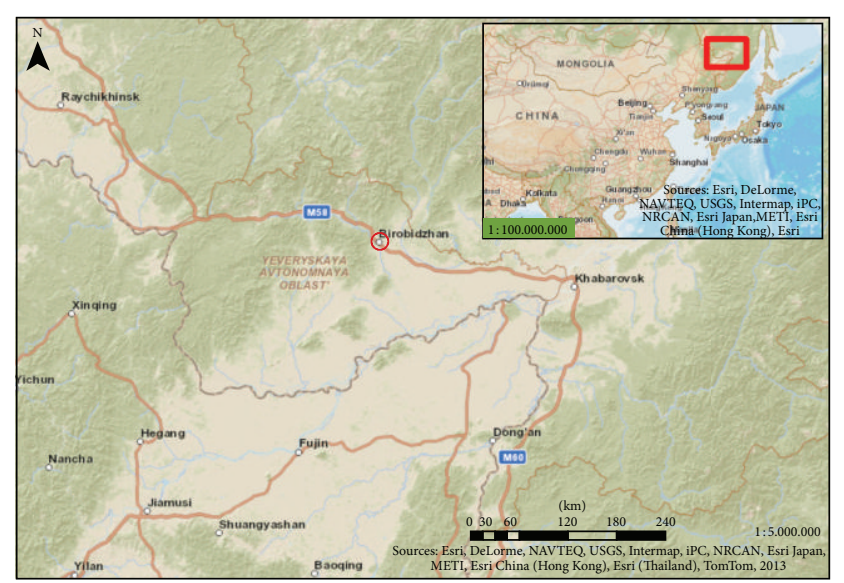

FIGURE 2: Regional and local position of Birobidzhan.

TABLE 1: Selected locations (zones) and their respective properties.

\begin{tabular}{lccc}
\hline Zone & Type & Build-up & Vegetation \\
\hline 1 & Residential & Dense & High \\
2 & Street & Medium & Light \\
3 & Square & Light & None \\
\hline
\end{tabular}

\section{Methods}

For the assessment of the human thermal bioclimate several indices have been developed over the last 50 years. Two thermal indices were used for this study, namely, the physiologically equivalent temperature (PET) and the universal thermal climate index (UTCI) [4, 15-17], both of which use the unit degrees Celsius and are based on models of human thermal balance. The meteorological data from the Birobidzhan WMO station (WMO index 31713) has been used as input for the calculation of the thermal indices, specifically the data for air temperature, wind velocity, wind direction, relative humidity, and cloud cover as a proxy value for the global radiation. These parameters have been recorded at the climate station in a three-hour interval, resulting in eight measuring points per day, for the 11-year period from 2000 to 2010.

Using this data and the RayMan model the thermal indices can be calculated $[9,10]$. Additionally the obstacle parameters at three different locations within the city were put into the model to determine their influence on the human thermal bioclimate. All three locations are highly frequented by the local population, but they are very different in terms of their structural specifications. Information for all three locations is summarised in Table 1. The terms used to describe "Build-up" and "Vegetation" are relative terms meant to compare the zones with each other. Pictures of the selected areas as well as fisheye pictures can be found in the appendix.

The meteorological data were made freely available via http://www.ogimet.com/ and were downloaded for the period from 2000 to 2010 in 3-hour intervals (01:00, 04:00, 07:00, 10:00, 13:00, 16:00, 19:00, and 22:00 local time). The availability of these meteorological measurements at eight points of time per day ensures a good temporal resolution of 


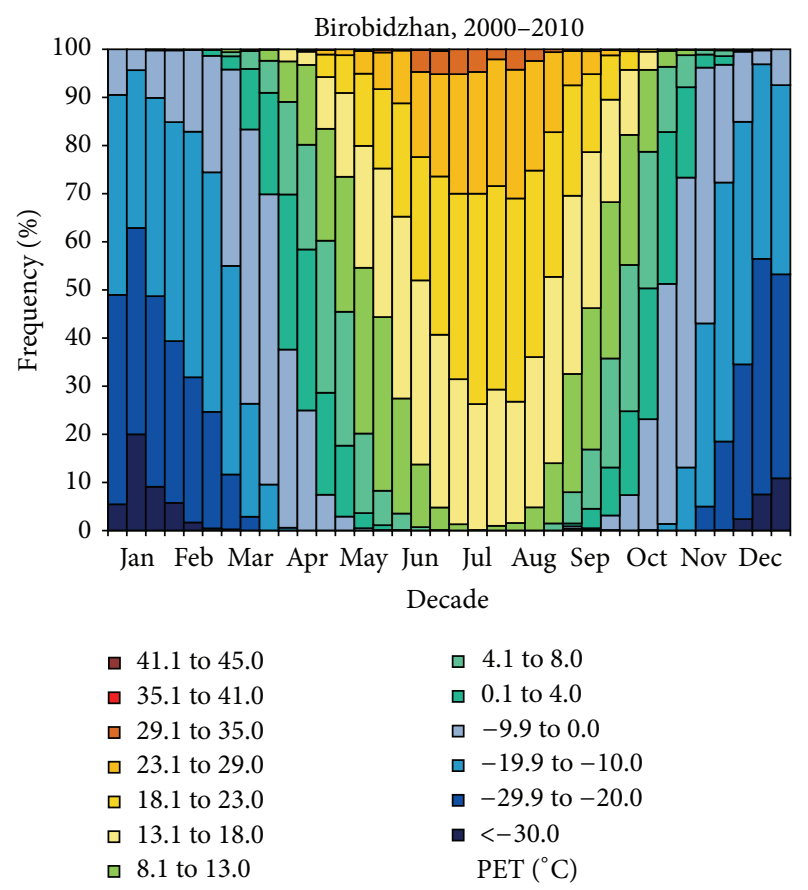

FIGURE 3: Mean frequency distribution of PET values in Birobidzhan, zone 1, during the year divided into 10-day intervals (decades) for the period 2000-2010.

the data. The data were initially available in SYNOP and had to be decoded to standard meteorological units. This was done using Microsoft Excel. All of the calculations and simulations in this study are based on the meteorological data obtained from this synoptic station and were modified only by the surrounding structures via obstacle files in RayMan which were based on maps of the city and local observation of the buildings. The general assumption for the transfer of the data is that air temperature and air humidity remain the same for the city and the rural station, and only wind speed, which is changed according to roughness, and radiation fluxes, which can be adjusted with the RayMan model, modify the indices.

\section{Results}

4.1. Physiologically Equivalent Temperature. The following section provides the results of PET in the context of the different building situations. It also includes its daily course for selected months in summer and winter. The overall results showed a great range of PET values being being between summer and winter seasons as well as between the different zones. The general effect of the building situation on PET is visualized in Table 2. The specific dynamics for each zone are discussed in Section 5 of this paper.

Figure 3 shows the mean decadal distribution of PET values in Zone 1 during the year. The lowest values can be found in the time from the end of November to the beginning of March. The highest frequency of extremely low values $\left(\mathrm{PET}<-30.0^{\circ} \mathrm{C}\right)$ is in the second decade of January with an occurrence frequency of $27.7 \%$. From the end of November until the midst of February PET values were not above $0.0^{\circ} \mathrm{C}$ as it is a period of constant frost. The highest PET values occur from the midst of June to the end of August. Values between $29.1^{\circ} \mathrm{C}$ and $41.0^{\circ} \mathrm{C}$ can be considered a fairly common phenomenon (about 14\%). With occurrence frequencies of about $1 \%$ values between $41.1^{\circ} \mathrm{C}$ and $45.0^{\circ} \mathrm{C}$ occur rather rarely. With about $30.9 \%$ the first decade of August shows the highest occurrence frequency of comfortable PET values between $18.1^{\circ} \mathrm{C}$ and $23.0^{\circ} \mathrm{C}$. Spring and autumn generally consist of PET values in the range of slight heat stress to extreme cold stress and require the most flexibility in terms of thermal adaption. In the summer months of July, June, and August PET does not drop to values below $0.0^{\circ} \mathrm{C}$.

Figure 4 shows the 2-dimensional daily and monthly courses of PET values in January and July, as an example for winter and summer, respectively. The $y$-axis shows the days of July and the $x$-axis shows the time steps according to the legend. The highest PET values can be expected towards the end of July around the 26th day and in general in the time between 13:00 and 16:00. During this time PET reaches values up to the range of $35.0^{\circ} \mathrm{C}$ to $41.0^{\circ} \mathrm{C}$. The coolest times of the day are the ones in the early morning between 4:00 and 7:00. Here PET values range between $13.0^{\circ} \mathrm{C}$ and $18.0^{\circ} \mathrm{C}$. In winter (January) PET drops to values below $-30.0^{\circ} \mathrm{C}$ and in extreme cases even below $-40.0^{\circ} \mathrm{C}$ creating extreme cold stress in terms of the human bioclimate. These extremely low values can be expected in the midst of January (exemplary for winter) in the early morning hours between 4:00 and 7:00. In general the highest PET values in winter do not reach the $0.0^{\circ} \mathrm{C}$ mark but rather stay considerably lower. They can be expected in the time between 13:00 and 16:00. From 16:00 on, PET drops until it reaches its lowest value in the time around 7:00. During January PET does not vary much, but there is an accumulation of very low values in the time from the 10th to the 17 th of January.

Zone 2 is less sheltered from solar radiation than zone 1 and therefore shows a tendency to have more extreme PET values. Since the climate data has been recorded at the same station the yearly change is the same as in zone 1 , but its amplitude is different. With $29.4 \%$ the frequency of PET values below $-30.0^{\circ} \mathrm{C}$ is about $2 \%$ higher than that in zone 1 (Figure 5). Still the winter months from the end of November until the end of February are consistenty below $0.0^{\circ} \mathrm{C}$, but the PET values are less extreme. In the summer months the occurrence frequency of comfortable PET values between $18.1^{\circ} \mathrm{C}$ and $23.0^{\circ} \mathrm{C}$ drops to $29.8 \%$, that is, $1 \%$ lower in comparison to zone 1 . The extremely high values that result in moderate to extreme heat stress increase in comparison. The frequency of values above $35.1^{\circ} \mathrm{C}$ does not increase much in a single-decade but rather occurs in more decades than it does in zone 1. In the summer season zone 2 displayed the same dynamics as zone 1, but there are more days with extreme PET values. Still the range leads up to about $41.0^{\circ} \mathrm{C}$ in the time between 13:00 and 16:00, but now these values can be found throughout the months. The coldest time of the day during July, used as an example, for summer is 4:00 with PET dropping to values around $10.0^{\circ} \mathrm{C}$. The daily course follows the classic pattern with the highest PET values occurring shortly after the sun reaches its zenith. The monthly course 

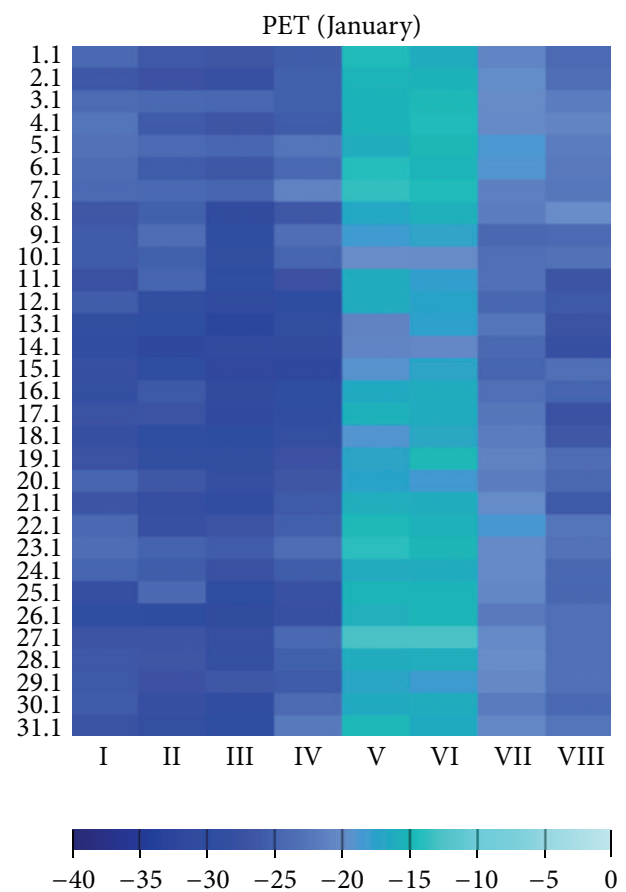

$\left({ }^{\circ} \mathrm{C}\right)$
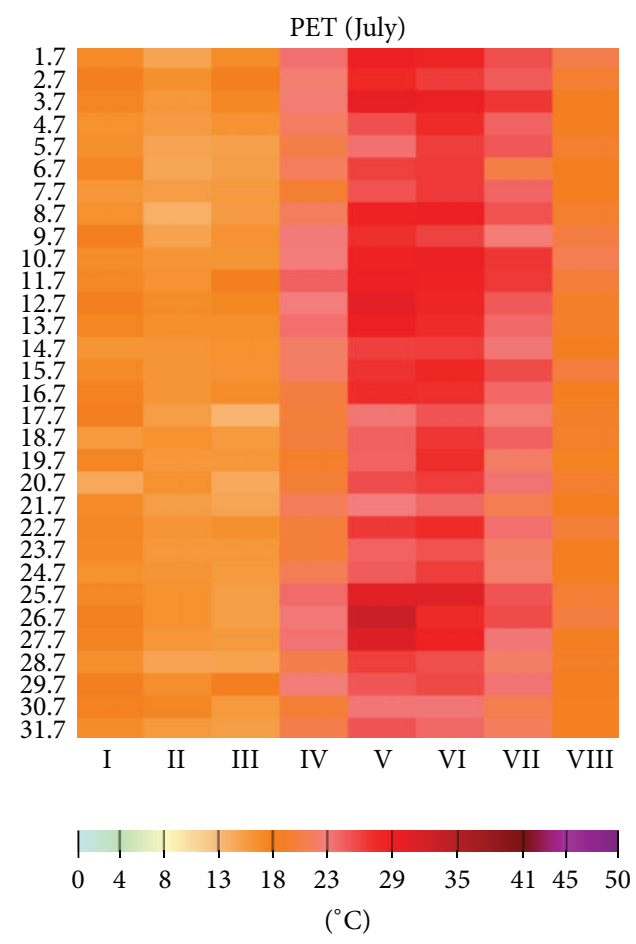

$\begin{array}{ll}\text { I: } 01: 00 & \text { V: } 13: 00 \\ \text { II: } 04: 00 & \text { VI: } 16: 00 \\ \text { III: } 07: 00 & \text { VII: } 19: 00 \\ \text { V: } 10: 00 & \text { VIII: } 22: 00\end{array}$

FIGURE 4: Monthly (along $y$-axis) and daily (along $x$-axis) dynamics of thermal comfort in winter (January) and summer (July) calculated with PET for Birobidzhan, zone 1.

TABLE 2: Mean number of days per year with PET values within a specific class for the 3 zones as well as the climate station in Birobidzhan (2000-2010).

\begin{tabular}{lcccc}
\hline PET $\left({ }^{\circ} \mathrm{C}\right)$ & WMO station & Zone 1 & Zone 2 & Zone 3 \\
\hline$<-30$ & 21.0 & 12.1 & 14.9 & 63.0 \\
$<-20$ & 68.3 & 59.4 & 114.6 & 60.5 \\
$<-10$ & 117.2 & 113.0 & 168.4 & 113.5 \\
$<0$ & 170.1 & 167.6 & 70.1 & 167.7 \\
$(15 \leq X \leq 30)$ & 65.4 & 72.3 & 40.5 & 72.2 \\
$(18 \leq X \leq 27)$ & 37.0 & 42.6 & 13.9 & 42.6 \\
$>29$ & 19.5 & 9.9 & 3.4 & 10.7 \\
$>35$ & 6.0 & 2.2 & 0.6 & 2.4 \\
$>41$ & 1.0 & 0.3 & 0.4 \\
\hline
\end{tabular}

does not show a very specific pattern but rather has an even distribution of values over the whole time with a few hotspots especially at 13:00. Winter in zone 2 displays a similar pattern as it does in zone 1, but as in summer the values are more extreme and there are more days with extremely low PET values. The time of the day they occur remains the same at 7:00. The warmest times of day are still the hours after the suns zenith between 13:00 and 16:00. Then the maximum values lie at about $-5.0^{\circ} \mathrm{C}$. At 22:00 PET starts to drop to values below $-30.0^{\circ} \mathrm{C}$ and reaches its minimum around 4:00 with values close to $-40.0^{\circ} \mathrm{C}$. A significant monthly pattern is not visible, but there is a cold spot in the second decade of January as it was observed before in the yearly course of PET for zone 2. Since zone 3 is the one with the lowest building density, it has the highest occurrence frequencies of extreme PET values. In Figure 6 the second decade of January showsthat $76.1 \%$ of all values are below $-20.0^{\circ} \mathrm{C}$. As a contrast in the first decade of July $17.8 \%$ of all PET values lie above $29.1^{\circ} \mathrm{C}$. With $26.1 \%$ of all values in the second decade of August situated in between $18.1^{\circ} \mathrm{C}$ and $23.0^{\circ} \mathrm{C}$ the maximum frequency of comfortable PET values is the lowest in comparison to the other two zones. The least extreme 


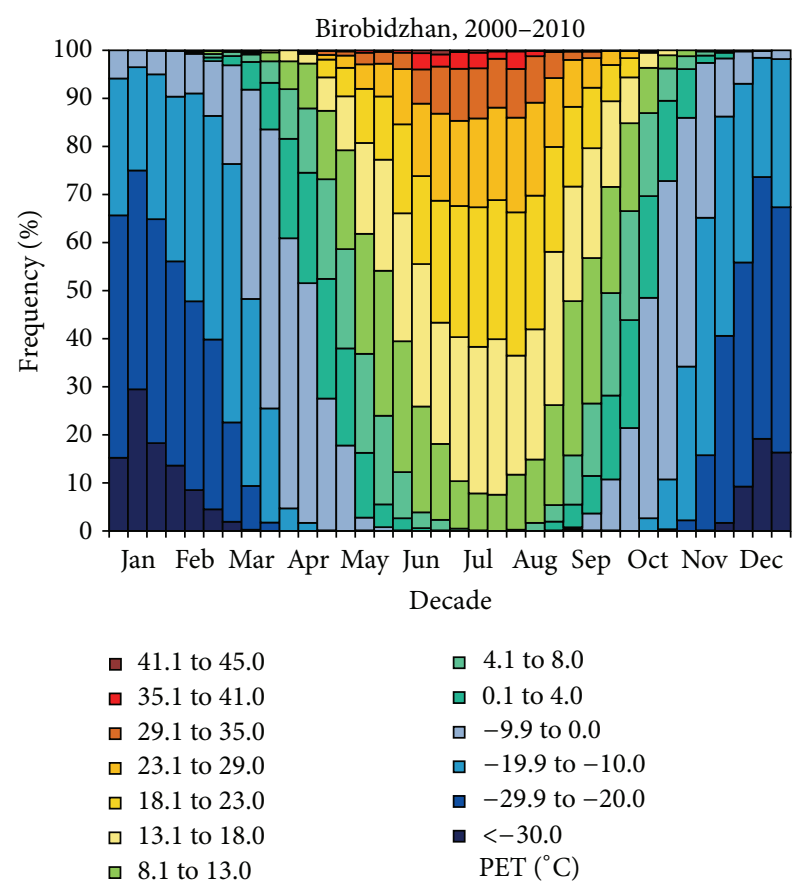

FIGURE 5: Mean frequency distribution of PET values in Birobidzhan, zone 2, during the year divided into 10-day intervals (decades) for the period 2000-2010.

times marked the end of spring and the beginning of autumn. Still they are not the ones with the highest frequency of comfortable values.

Instead they have a tendency to cold stress with the majority of the values between comfort and strong cold stress. The pattern of maximum and minimum values remains the same in zone 3 since similar meteorological input data were used. However the amplitude of those values reaches its maximum. The hottest time of day was 13:00 with PET values even above $41.0^{\circ} \mathrm{C}$. Around 4:00 PET reaches its minimum of about $8.0^{\circ} \mathrm{C}$ on some days. Usually even then PET does not drop to single digit values but stays in between $13.0^{\circ} \mathrm{C}$ and $18.0^{\circ} \mathrm{C}$. The hottest time of July seems to be the end of the first decade and the beginning of the second. The most comfortable times of the day are the hours from 22:00 to 1:00. At that time most PET values lie in between $18.0^{\circ} \mathrm{C}$ and $23.0^{\circ} \mathrm{C}$. In January the coldest time of day in zone 3 was around 7:00 so about the same time as in zones 1 and 2. The PET values drop below $-40.0^{\circ} \mathrm{C}$ at that time, especially in the ten days from the 8th of January to the 18th of January. The warmest times of the day are still occur between 13:00 and 16:00 making the afternoon and early evening the most pleasant times of the day to be outside on the city square. Still the PET values at that time of day result in extreme cold stress and remain below $0.0^{\circ} \mathrm{C}$. Even around 13:00 PET values are closer to $-15.0^{\circ} \mathrm{C}$ than they are to $0.0^{\circ} \mathrm{C}$. A day with PET values of single digits below $0.0^{\circ} \mathrm{C}$ could therefore be considered a comparatively warm day.

4.2. Universal Thermal Climate Index. In general the UTCI values follow the same pattern as the PET values, which is to

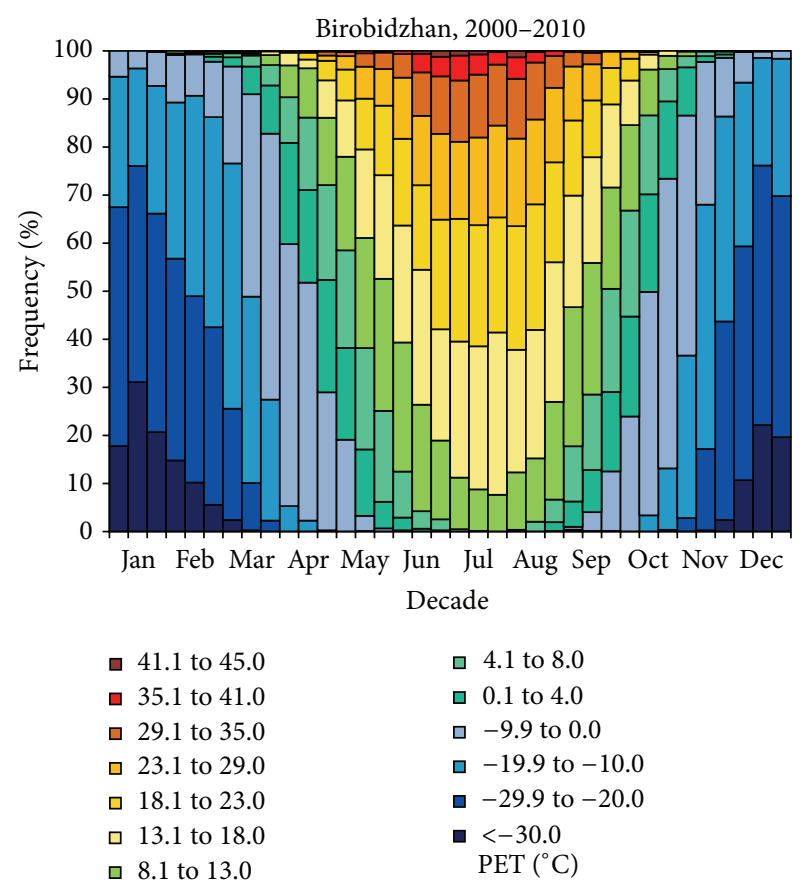

FIgURE 6: Mean frequency distribution of PET values in Birobidzhan, zone 3 , during the year divided into 10-day intervals (decades) for the period 2000-2010.

be expected since both of the indices are based on the human energy budget and are calculated using the same datasets (Table 3).

However the adaptive nature of the UTCI index results in less extreme and more moderate values since clothing and activity are adapted to the surrounding thermal conditions [13]. This presents the opportunity of a more detailed and diverse look at the thermal comfort.

Zone 1 is still the most sheltered and therefore the most comfortable zone. The equivalent temperature calculated with UTCI actually showed more comfortable conditions than that with PET. The adaption of the clothing insulation in combination with the wide range of nonstressful values from $9.0^{\circ} \mathrm{C}$ to $23.0^{\circ} \mathrm{C}$ results in a wide range of stress-free UTCI values from spring to autumn with a maximum of comfort in summer. Still the summer months hold more than $30 \%$ of moderate to very strong heat stress conditions and winter still remains a time of cold stress varying from extreme to moderate cold stress which makes winter the most stressful time for the human body in terms of the thermal bioclimate. Following the UTCI scale Figure 7 represents the monthly and daily courses of thermal conditions for January and July in zone 1 . The warmest time of the day is the time between 13:00 and 16:00, while the lowest values occur between 4:00 and 7:00 although cold stress does not occur. During the warmest time of the day, UTCI reached moderate heat stress values on several occasions. But in general July can be considered a comfortable month. The monthly course showed three phases of high UTCI values with the first being in the beginning of the first decade, the second at the end of the first decade, and the third in the middle of the third decade. 

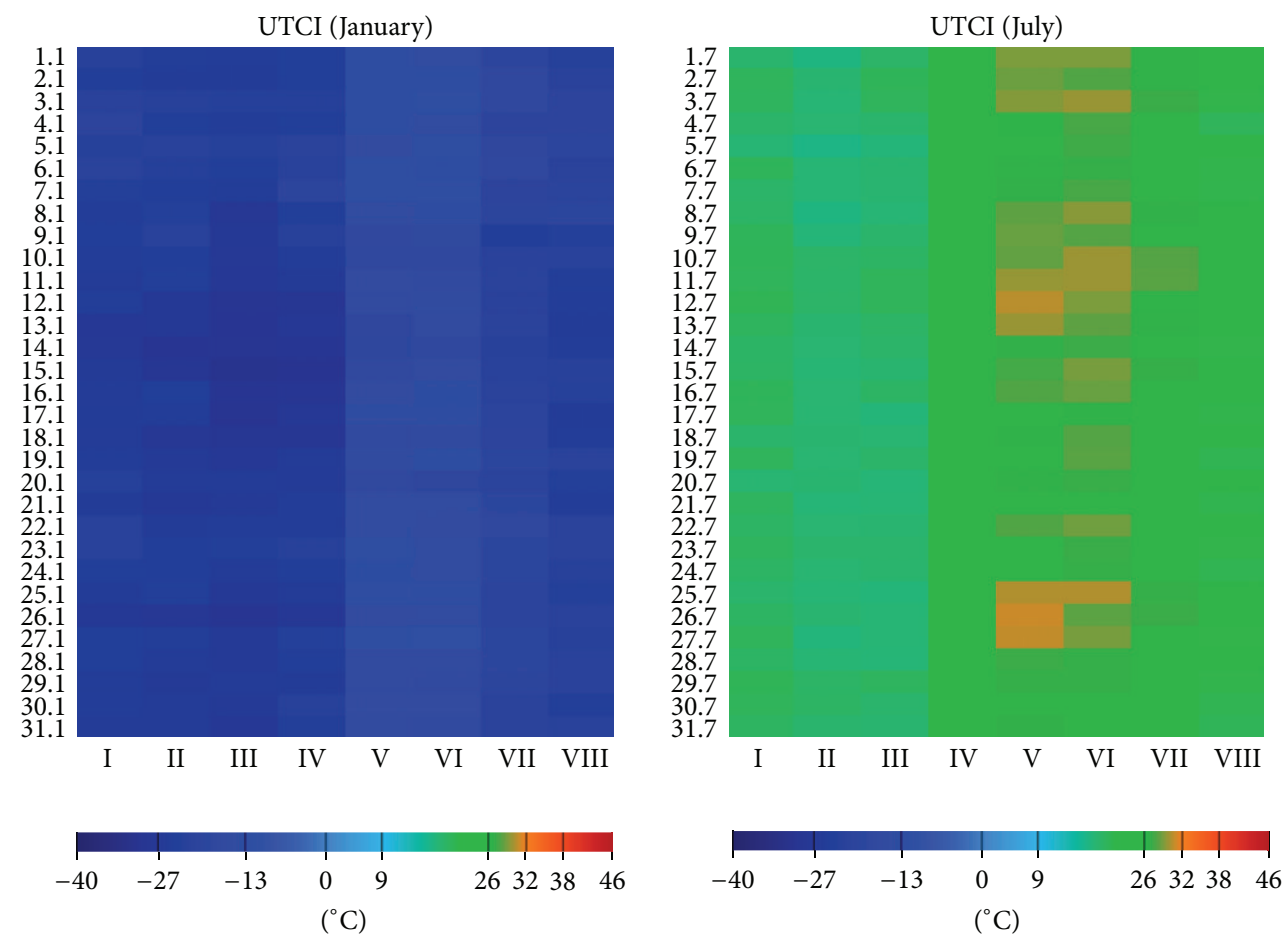

$\begin{array}{ll}\text { I: } 01: 00 & \text { V: } 13: 00 \\ \text { II: } 04: 00 & \text { VI: } 16: 00 \\ \text { III: } 07: 00 & \text { VII: } 19: 00 \\ \text { V: } 10: 00 & \text { VIII: } 22: 00\end{array}$

FIGURE 7: Monthly and daily dynamics of thermal comfort in winter (January) and summer (July) calculated with UTCI for Birobidzhan, zone 1.

TABLE 3: Mean number of days per year with UTCI values within a specific class for the 3 zones as well as for the climate station in Birobidzhan (2000-2010).

\begin{tabular}{lcccc}
\hline UTCI $\left({ }^{\circ} \mathrm{C}\right)$ & WMO station & Zone 1 & Zone 2 & Zone 3 \\
\hline$<-30$ & 21.0 & 9.0 & 10.5 & 5.4 \\
$<-20$ & 68.3 & 54.8 & 109.6 & 55.8 \\
$<-10$ & 117.2 & 108.7 & 157.0 & 109.1 \\
$<0$ & 170.1 & 156.1 & 90.6 & 156.1 \\
$(15 \leq X \leq 30)$ & 65.4 & 91.7 & 55.8 & 92.5 \\
$(18 \leq X \leq 27)$ & 37.0 & 57.6 & 13.5 & 57.8 \\
$>29$ & 19.5 & 10.1 & 1.3 & 10.9 \\
$>35$ & 6.0 & 1.1 & 0.0 & 0.0 \\
$>41$ & 1.0 & 0.0 & & 0.0 \\
\hline
\end{tabular}

Winter (exemple in this case January) in zone 1 presents itself to be much less comfortable than summer. The daily course remains the same with the warmest time being between 13:00 and 16:00 and the coldest around 7:00. In contrast to summer there were no periods without thermal stress. Throughout the whole month the body suffers from moderate to very strong cold stress. The highest values lie between $0.0^{\circ} \mathrm{C}$ and $-13.0^{\circ} \mathrm{C}$ while the coldest are close to $-40.0^{\circ} \mathrm{C}$. The coldest time of January is in the middle of the second decade from the 12th until the 17th of January, while the highest values occurred at 13:00 between the 23rd and the 27th (Figure 7).
The thermal dynamics in zone 2 were observed to be similar to those in zone 1 but with about $5 \%$ more heat stress in the summer months. Comfortable values occurred from the midst of March until the end of October. The month with the most heat stress is July with its second decade being the one with almost $30 \%$ of heat stress values. Winter still presented a time of constant cold stress varying in its intensity from extreme to moderate and with the second decade of January as the coldest period of the year. With about $42.1 \%$ of all values below $-27.0^{\circ} \mathrm{C}$ this decade showed the highest frequency of very strong cold stress values. The second decade 
of December shows $92.4 \%$ of all values being below $-13.0^{\circ} \mathrm{C}$ resulting in at least strong cold stress conditions. As in zone 1 , the summer months are the ones that present the most comfortable outdoor conditions but also the most heat stress. The thermal dynamics of zone 2 for July were used as an example for the thermal dynamics in summer. The time of the highest thermal stress is the time between 13:00 and 16:00 with UTCI values above $32.0^{\circ} \mathrm{C}$. Also around 10:00 and 19:00 the human body can experience slight heat stress on some days. The coldest time of the day is the time between 4:00 and 7:00. During this time the values drop almost to the range of cold stress. In the course of July there are three hot spots. The first two occurr in the first decade while the last hotspot lies in the middle of the third decade. Winter in zone 2 presents itself with constant cold stress. In January the highest values for UTCI occur in the afternoon between 13:00 and 16:00. During this time UTCI lies between $0.0^{\circ} \mathrm{C}$ and $-13.0^{\circ} \mathrm{C}$ causing moderate to strong cold stress. In the course of the night the values start to drop to reach their minimum values below $-27.0^{\circ} \mathrm{C}$ around 4:00 to 7:00. At this time the human body experiences very strong cold stress. The coldest time of January is between the 10th and the 16th, while the, least cold days are closer to the end of the month.

Since it has the most open space, zone 3 presents itself with the least comfortable thermal conditions. The summer months show the highest frequency of heat stress values, while, in winter the frequency of strong and very strong cold stress is increased. Still summer shows the most comfortable setting with up to $70 \%$ of all values being within one decade in the class of $9.0^{\circ} \mathrm{C}$ to $27.0^{\circ} \mathrm{C}$. The highest heat stress occurs in summer around the same time in the middle of July and the beginning of August. In winter the human body experiences exclusively cold stress with $43.9 \%$ of all values being between $-27.0^{\circ} \mathrm{C}$ and $39.9^{\circ} \mathrm{C}$; the second decade of January shows the most extreme conditions; while the second decade of December can be considered the coldest in general with $92.6 \%$ of all values below $-13.0^{\circ} \mathrm{C}$. Times of no thermal stress occur from the midst of March to the midst of November even though they are very rare at those times. In spring and autumn the range of UTCI covers everything from thermal stress to strong cold stress and in rare cases even heat stress. The warmest time of day in zone 3 in summer is still the time from 13:00 to 16:00, but the occurrence of UTCI values outside the range of no thermal stress around 10:00 and 19:00 is increased. Also the three hotspots in the monthly course that could be observed in zones 1 and 2 are not as prominent because they are closer together and cover more days. From 22:00 to 7:00 the values are the lowest with a minimum around 4:00. Still they do not present any cold stress since they stay quite far above $9^{\circ} \mathrm{C}$. In zone 3 the winter season presents itself with the same dynamics as those in the other zones. It shows its coldest period in January from the 8th to the 17th in the monthly course and in general from 4:00 to 7:00 in the daily course. The warmest time of the day is the time between 13:00 and 16:00 but even then the UTCI values do not exceed the range of cold stress. In the coldest hours UTCI values drop far below $-27.0^{\circ} \mathrm{C}$ and get close to $-40.0^{\circ} \mathrm{C}$.

\section{Discussion}

The results of the calculations and simulations as well as the measurements of the meteorological parameters show a clear picture of the thermal conditions in terms of the human bioclimate in the JAR. In general it can be concluded that the JAR has a very big gradient of thermal conditions throughout the year not only in the direct thermal parameters such as $T_{a}$ and $T_{\mathrm{mrt}}[23,24]$ but also in the secondary parameters such as VP and RH. The wind is not so much bound to an annual cycle and therefore influences the thermal conditions in a similar pattern throughout the year. The thermal comfort has been determined with PET and UTCI and they exhibited similar dynamics in the annual course. However they indicate a great difference in their values. While PET shows a lot of very extreme values and only little thermal comfort throughout the year, UTCI shows a lot of nonstressful conditions especially in the summer months. This difference was to be expected since PET has been calculated with the same base parameters for the entire year while UTCI is an adaptive index which results in a less extreme setting. Since it can be assumed that no one is wearing a light business suit (clo $=0.9)$ in winter in the Russian Far East the adaption of this parameter seems to result in a more realistic assessment. Still the winter season holds a lot of cold stress and in contrast to summer has no comfortable values at all.

In case of cold stress in winter it does not matter whether it is calculated with PET or UTCI. In both cases winter is not comfortable. The only difference is the range of values. While calculated with PET there are more extreme cold stress values, UTCI results strong rather in than extreme cold stress. The thermal conditions in summer, however, differ greatly depending on the applied index. While PET depicts a rather harsh picture of the thermal conditions in summer, UTCI shows a lot of nonstressful values. This difference is the result of the different procedures of calculating the indices as well as the different index classes applied to the definitions of thermal comfort. While PET provides only a narrow window of thermal comfort $\left(18.0^{\circ} \mathrm{C}\right.$ to $\left.23.0^{\circ} \mathrm{C}\right)$, UTCI considers a much wider range $\left(9.0^{\circ} \mathrm{C}\right.$ to $\left.27.0^{\circ} \mathrm{C}\right)$ comfortable or at least not stressful for the human body $[2,3,5]$. The result of this calculation is a very comfortable thermal situation in summer with about $30 \%$ of the values resulting in slight to strong heat stress and the remaining 70\% being comfortable. PET shows most of the variability in its classed values during summer. It shows little thermal comfort but wide rather a range from extreme heat stress to moderate cold stress. How wide the range of PET or UTCI is and how narrow the window of comfortable values is depend on the surrounding structures as well. The higher the building density is in an area and the more vegetation there is, the more comfortable are outdoor conditions are. In summer this is the result of shading effects and the resulting reduction of $T_{\mathrm{mrt}}$ and in winter the high urban density results in a reduction of heat loss due to long wave radiation. As a result the outdoor areas of the residential area (zone 1) can be considered the most comfortable one throughout the year while the city square (zone 3 ) is the least comfortable due to its high exposure to the elements. 


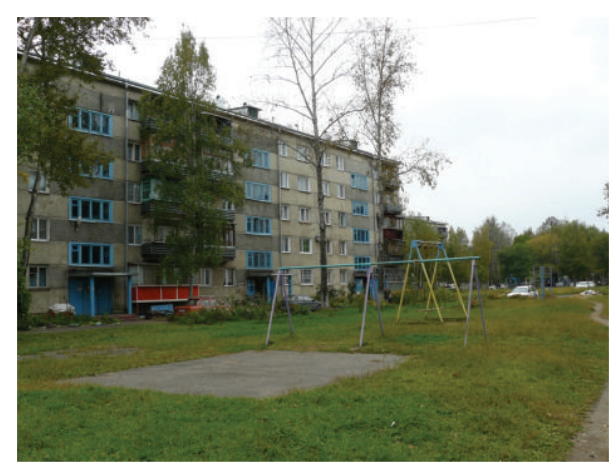

FIgURE 8: Residential area in Birobidzhan (zone 1).

The results also show the influence of all the parameters that are part of the calculations of PET. The higher the relative humidity is the more extreme is the thermal impact of $T_{a}$ and $T_{\text {mrt }}$ is. The wind always has a cooling effect (except when the air temperature is higher than the surface temperatures of humans), but its role in this region is very important since the occurrence of high wind velocities is rather rare. The main impact on the human thermal bioclimate in this region lies with the air temperature and the mean radiant temperature. Therefore the best possibilities for human interference lie in the reduction of irradiation. Using wind channelling to reduce $T_{a}$ in summer seems premature since the same action would lead to even more extreme cold stress during winter. Another way to reduce thermal stress in urban areas of the JAR would be the increase of vegetation.

According to a paper on thermal strain due to a change in locations within the Russian Far East [25] the difference in thermal comfort during the winter months is negligible due to an overall extreme cold stress which makes the results of this study applicable for the whole region in winter. In summer, however, the thermal conditions within the Far East district vary greatly making more localized investigations necessary for a thorough assessment of preferable urban outdoor structures in summer.

On the topic of the change of extreme climate regions due to global climate change it can be assumed that the overall frequency of extremely cold days is reduced in favour of an increase in heat stress days which would lead to an overall increase in thermal comfort for regions of high cold stress [26]. In a region of high gradients of thermal comfort like the JAR, however, the result would rather be a shift in types of thermal discomfort than an increase of comfortable days.

In comparison, Freiburg in south western Germany which lies at the same latitude $\left(48^{\circ} \mathrm{N}\right)$ but at a very different longitude $\left(9^{\circ} \mathrm{E}\right)$ than Birobidzhan $\left(127^{\circ} \mathrm{E}\right)$ has a very different climate setting. In Birobidzhan the annual climate variation is much higher and is based on the summer monsoon or the Siberian high pressure area. In Freiburg climate is much more dependent on the pressure systems in the northern Atlantic especially the Northern Atlantic Oscillation (NAO) and the interaction with the alpine climate system. As a result the climate in Freiburg is much less extreme. In particular in winter the thermal parameters show a much more moderate

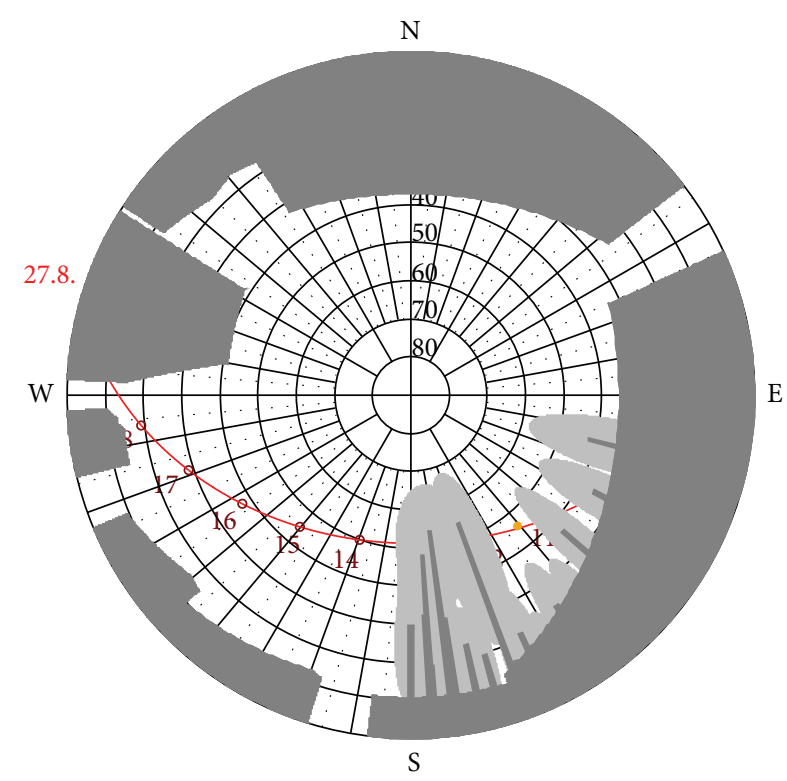

1999-2010 RayMan Pro 2.1

Figure 9: Polar diagram for the sky view factor (zone 1) in Birobidzhan.

situation $[22,27,28]$. In summer being located on a wide open space with close to no vegetation Freiburg and Birobidzhan present similar heat stress conditions [27-29]. This difference in climate situations shows a longitudinal dependency of the regional climate that is not at all linked to the classic climate zones which depend on the latitude but rather to its proximity to pressure systems and its location in the path of meteorological phenomena such as a monsoon or El Niño.

\section{Conclusions}

After analysing the results of measurements and calculations it can be concluded that the JAR is a climatic extreme region with a massive gradient of thermal comfort conditions. However there is a variety of possibilities for adaption to this phenomenon. The first and most simple one is of course to follow the saying "there is no bad weather, just a bad choice of clothing" and to choose the right clothing for the meteorological situation. This action is taken into consideration in the application of UTCI and it shows a significant moderation of the otherwise unpleasant conditions in late spring, summer, and early autumn. In the cold season, however, even clothing does not help much. It moderates the extreme cold stress but it does not suffice to relieve the human body entirely. To gain a maximum of cold stress reduction it is therefore necessary to make sure that one stays outside as little as possible and-if one does stay outside-to choose the location wisely. According to the results of this study the wisest decision would be to avoid wide open spaces and to remain in areas of high urban density. Another important factor is of course the time of the day. While it is advisable to choose the morning and late afternoon hours of the day and to avoid noon and early afternoon for outside chores in summer, the opposite 


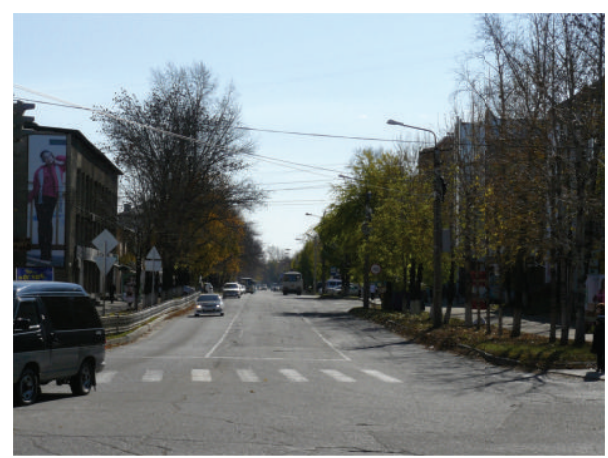

FIGURE 10: Main street in Birobidzhan (zone 2).

$\mathrm{N}$

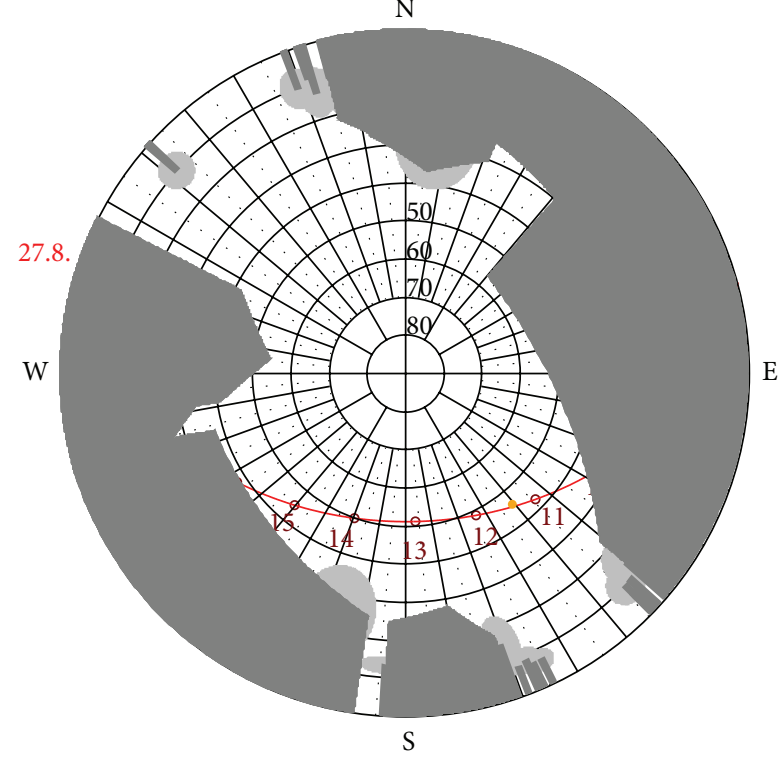

1999-2010 RayMan Pro 2.1

FIgURE 11: Polar diagram for the sky view factor (zone 2) in Birobidzhan.

can be said about winter. The least thermal stress in winter occurs for all zones in the time between 13:00 and 16:00 which makes it the most pleasant time to be outside. Staying outside at night especially in the hours of early morning around 4:00 would be ill advised since those are the hours of the strongest cold stress.

For planning purposes in this region or regions affected by a similar climate it can be concluded that a high urban density combined with a fair amount of inner city vegetation would be a preferable setting to reduce thermal stress. This measure would be especially preferable for locations that are equally important throughout the year such as public transport stops, train stations, or other points of public interest.

\section{Appendix}

See Figures 8, 9, 10, 11, 12, and 13 .

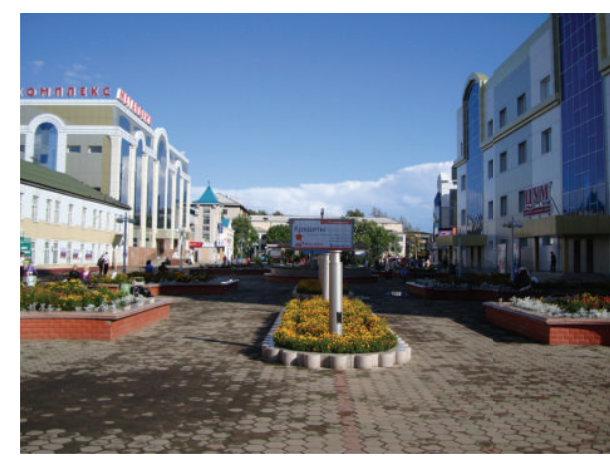

Figure 12: Square in Birobidzhan (zone 3).

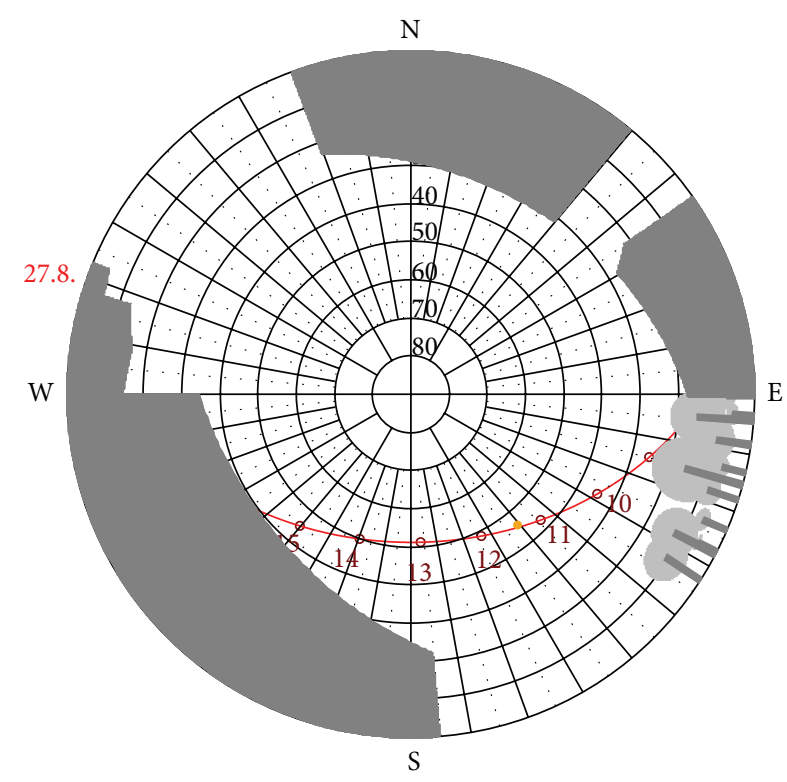

1999-2010 RayMan Pro 2.1

Figure 13: Polar diagram for the sky view factor (zone 3) in Birobidzhan.

\section{References}

[1] P. Höppe, Die Energiebilanz des Menschen [M.S. thesis], Wissenschaftliche Mitteilungen des Meteorologischen Instituts Universität München, 1984.

[2] P. Höppe, "The physiological equivalent temperature-a universal index for the biometeorological assessment of the thermal environment," International Journal of Biometeorology, vol. 43, no. 2, pp. 71-75, 1999.

[3] A. Matzarakis, H. Mayer, and M. G. Iziomon, "Applications of a universal thermal index: physiological equivalent temperature," International Journal of Biometeorology, vol. 43, no. 2, pp. 76-84, 1999.

[4] D. Fiala, G. Havenith, P. Bröde, B. Kampmann, and G. Jendritzky, "UTCI-Fiala multi-node model of human heat transfer and temperature regulation," International Journal of Biometeorology, vol. 56, no. 3, pp. 429-441, 2012.

[5] G. Jendritzky, R. de Dear, and G. Havenith, "UTCI-Why another thermal index?” International Journal of Biometeorology, vol. 56, no. 3, pp. 421-428, 2012. 
[6] H. Mayer and P. Höppe, "Thermal comfort of man in different urban environments," Theoretical and Applied Climatology, vol. 38, no. 1, pp. 43-49, 1987.

[7] P. R. Höppe, "Heat balance modelling," Experientia, vol. 49, no. 9, pp. 741-746, 1993.

[8] P. Höppe, "Die Wärmebilanzmodelle MEMI und IMEM zur Bewertung der thermischen Beanspruchung am Arbeitsplatz," Verhandlungen der Deutschen Gesellschaft für Arbeitsmedizin und Umweltmedizin, vol. 34, pp. 153-158, 1994.

[9] A. Matzarakis, F. Rutz, and H. Mayer, "Modelling radiation fluxes in simple and complex environments-application of the RayMan model," International Journal of Biometeorology, vol. 51, no. 4, pp. 323-334, 2007.

[10] A. Matzarakis, F. Rutz, and H. Mayer, "Modelling radiation fluxes in simple and complex environments: basics of the RayMan model," International Journal of Biometeorology, vol. 54, no. 2, pp. 131-139, 2010.

[11] R.-L. Hwang, T.-P. Lin, and A. Matzarakis, "Seasonal effects of urban street shading on long-term outdoor thermal comfort," Building and Environment, vol. 46, no. 4, pp. 863-870, 2011.

[12] T.-P. Lin, A. Matzarakis, and R.-L. Hwang, "Shading effect on long-term outdoor thermal comfort," Building and Environment, vol. 45, no. 1, pp. 213-221, 2010.

[13] K. Blazejczyk, Y. Epstein, G. Jendritzky, H. Staiger, and B. Tinz, "Comparison of UTCI to selected thermal indices," International Journal of Biometeorology, vol. 56, no. 3, pp. 515$535,2012$.

[14] A. Psikuta, D. Fiala, G. Laschewski et al., "Validation of the Fiala multi-node thermophysiological model for UTCI application," International Journal of Biometeorology, vol. 56, no. 3, pp. 443460, 2012.

[15] D. Fiala, K. J. Lomas, and M. Stohrer, "A computer model of human thermoregulation for a wide range of environmental conditions: the passive system," Journal of Applied Physiology, vol. 87, no. 5, pp. 1957-1972, 1999.

[16] D. Fiala, K. J. Lomas, and M. Stohrer, "Computer prediction of human thermoregulatory and temperature responses to a wide range of environmental conditions," International Journal of Biometeorology, vol. 45, no. 3, pp. 143-159, 2001.

[17] D. Fiala, K. J. Lomas, and M. Stohrer, "First principles modeling of thermal sensation responses in steady-state and transient conditions," in Technical and Symposium Papers Presented at the 2003 Winter Meeting of the ASHRAE, pp. 179-186, January 2003.

[18] E. Grigorieva and V. Tunegolovets, "Change of climate on the south of the Russian Far East in the second half of the 20th century," Annalen Der Meteorologie, vol. 41, pp. 209-212, 2005.

[19] E. Grigorieva and D. Fetisov, "Estimation of climatic resources for summer sport recreation," in The Jewish Autonomous Region of Russia, Developments in Tourism Climatology, pp. 87-92, 2007.

[20] E. Grigorieva, "Spatial-temporal dynamics of climate thermal resources for the southern part of the Russian Far East," in Proceedings of the 18th International Congress of Biometeorology, $\mathrm{p}$. 121, International Society of Biometeorology, Tokyo, September 2008.

[21] E. Grigorieva, A. Matzarakis, and C. R. de Freitas, "Analysis of growing degree-days as a climate impact indicator in a region with extreme annual air temperature amplitude," Climate Research, vol. 42,, pp. 143-154, 2010.

[22] E. Grigorieva and A. Matzarakis, "Physiologically equivalent temperature as a factor for tourism in extreme climate regions in the Russian Far East: preliminary results," European Journal of Tourism, Hospitality and Recreation, vol. 3, pp. 127-142, 2011.
[23] P. O. Fanger, Thermal Comfort, McGraw-Hill, New York, NY, USA, 1972.

[24] VDI, Environmental Meteorology, Methods for the Human Biometeorological Evaluation of Climate and Air Quality for the Urban and Regional Planning at Regional Level. Part I. Climate, VDI/DIN-HandbuchReinhaltung der Luft, Düsseldorf, Germany, 1998.

[25] C. R. de Freitas and E. A. de Grigorieva, "The acclimatization thermal strain index (ATSI): a preliminary study of the methodology applied to climatic conditions of the Russian Far East," International Journal of Biometeorology, vol. 53, no. 4, pp. 307315, 2009.

[26] D. H. W. Li, K. K. W. Wan, L. Yang, and J. C. Lam, "Heat and cold stresses in different climate zones across China: a comparison between the 20th and 21st centuries," Building and Environment, vol. 46, no. 8, pp. 1649-1656, 2011.

[27] D. Fröhlich and A. Matzarakis, "Heat stress and city planningthe example of the "Platz der alten synagoge" in Freiburg in Breisgau," Gefahrstoffe Reinhaltung der Luft, vol. 71, no. 7-8, pp. 333-338, 2011.

[28] J. Herrmann and A. Matzarakis, "Mean radiant temperature in idealised urban canyons-examples from Freiburg, Germany," International Journal of Biometeorology, vol. 56, no. 1, pp. 199203, 2012.

[29] A. Matzarakis and C. Endler, "Climate change and thermal bioclimate in cities: impacts and options for adaptation in Freiburg, Germany," International Journal of Biometeorology, vol. 54, no. 4, pp. 479-483, 2010. 

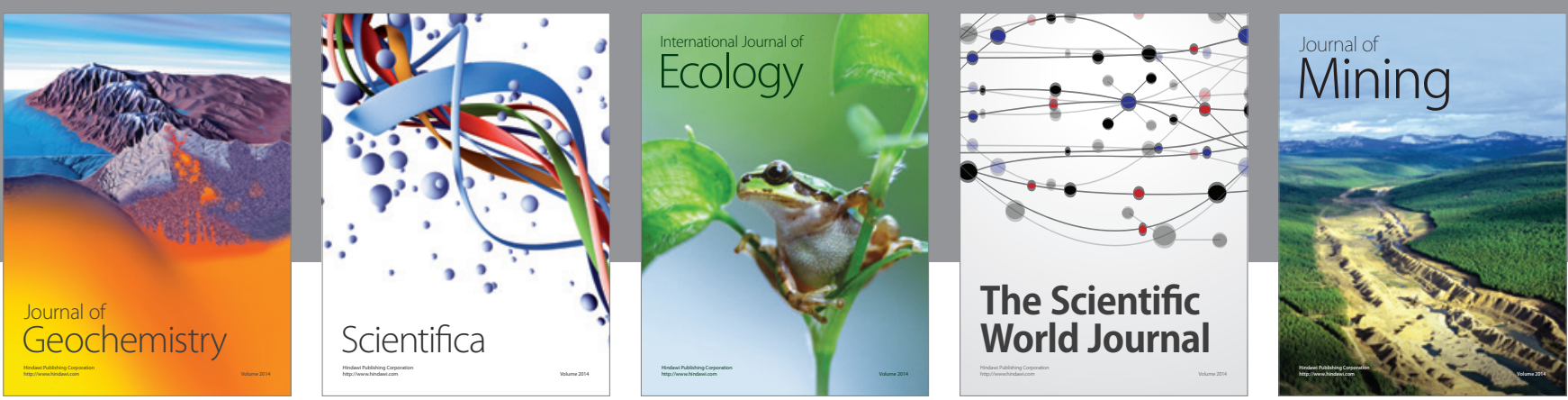

The Scientific World Journal
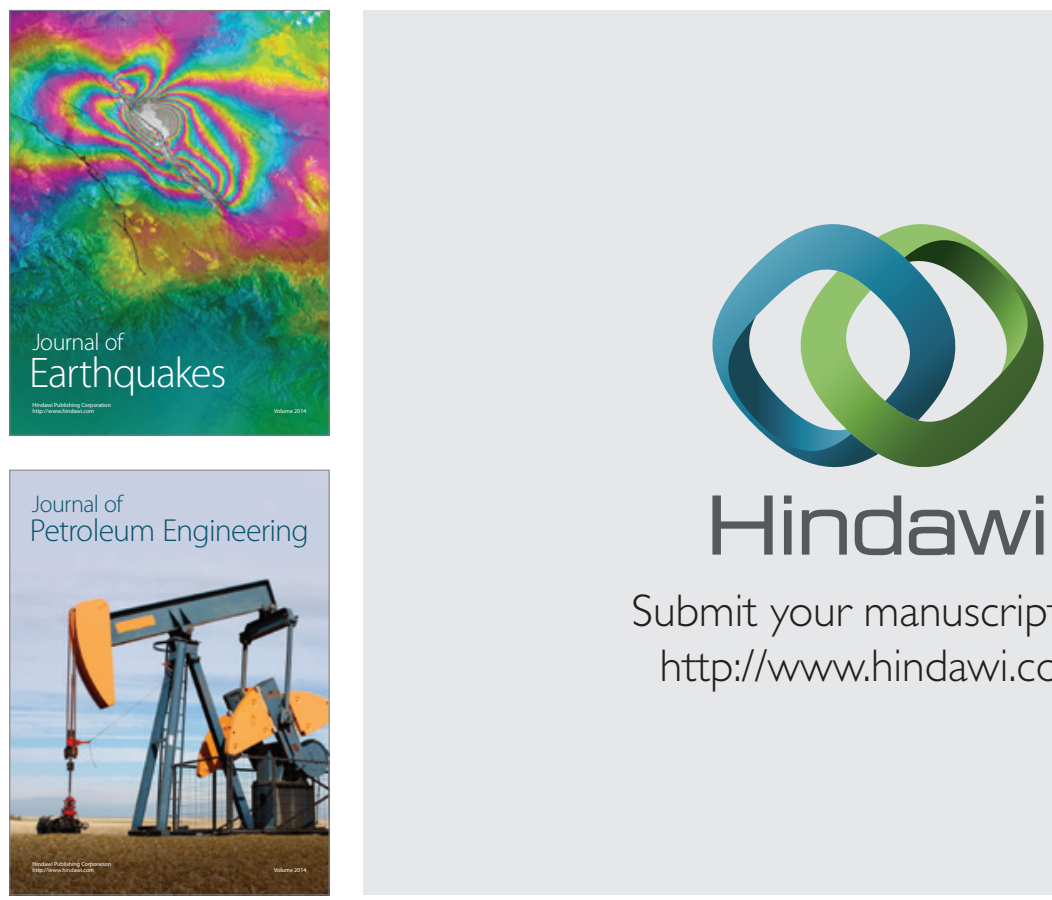

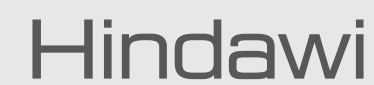

Submit your manuscripts at

http://www.hindawi.com
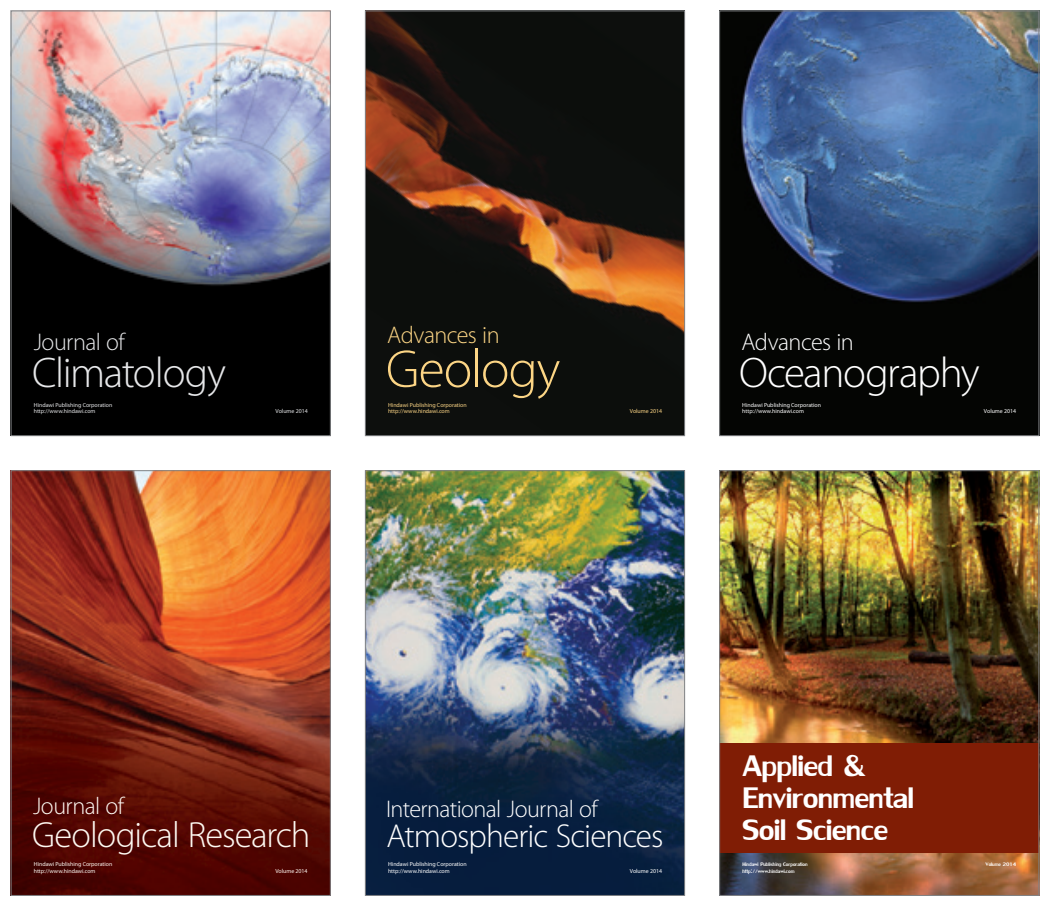
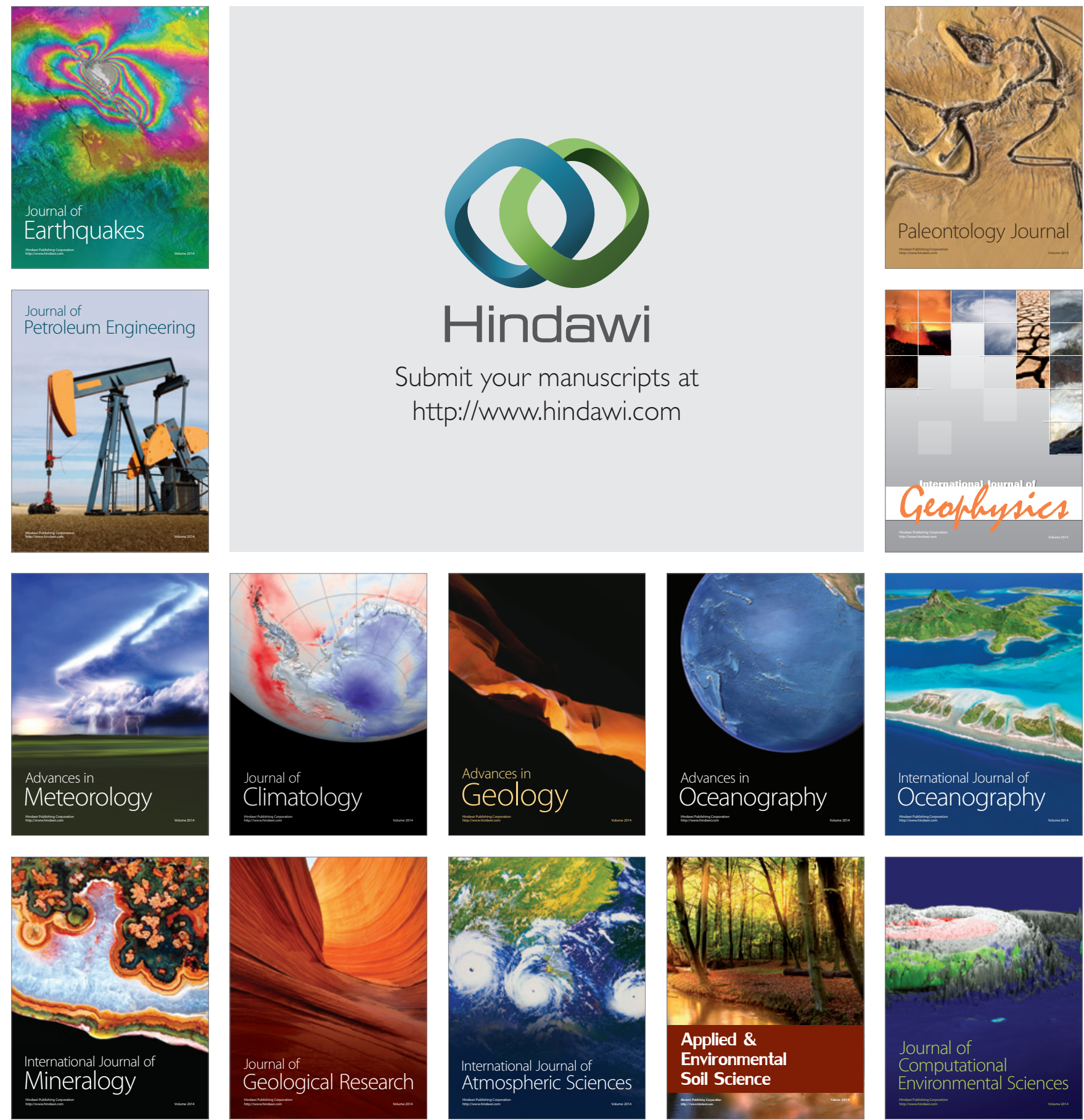